\title{
X-ray microtomography (XMT) of fossil brachiopod shell interiors for taxonomy
}

Błażej Błażejowski, Marcin Binkowski, Maria Aleksandra Bitner, and Piotr Gieszcz

Acta Palaeontologica Polonica 56 (2), 2011: 439-440 doi: http://dx.doi.org/10.4202/app.2010.0114

The ability to see and understand the three-dimensional structure of an investigated object plays a key role in studying fossil remains. All living organisms are formed in three-dimensions, but unfortunately fossilization processes often reduce overall shape, making it difficult to gather information about real overall appearance, functionality, and inner structure. Here, using a specimen of the brachiopod Terebratula terebratula we demonstrate a non-destructive technique for exploring the 3-D internal structure of fossil remains. The use of tomography allows the construction of a set of transverse serial sections in the manner used by brachiopod researchers for decades.

Błażej Błażejowski [bblazej@twarda.pan.pl] and Maria Aleksandra Bitner [bitner@twarda.pan.pl ], Institute of Paleobiology PAS, Twarda 51/55, Warsaw PL 00-818 Poland; ; Marcin Binkowski [marcin.binkowski@us.edu.pl], Department of Biomedical Computer Systems, Silesia University, Będzińska 39, 41-200

Sosnowiec, Poland; Piotr Gieszcz [p.gieszcz@twarda.pan.pl], Association of Polish Climatologists, ul. Międzynarodowa 58/36, 03-922 Warszawa, Poland.

This is an open-access article distributed under the terms of the Creative Commons Attribution License (for details please see creativecommons.org), which permits unrestricted use, distribution, and reproduction in any medium, provided the original author and source are credited. 

